Johns, A. T. (1951). J. gen. Microbiol. 5, 337-345.

\title{
The Mechanism of Propionic Acid Formation by Propionibacteria
}

\author{
By A. T. JOHNS \\ Biochemistry Department and Agricultural Research Unit of Animal \\ Physiology, University of Cambridge
}

SUMMARY: The main mechanism for propionic acid formation by organisms of the genus Propionibacterium is by the decarboxylation of succinic acid. The varying ratios of propionic to acetic acid reported in the literature as a result of the fermentation of glucose are attributed to differences in carbon dioxide tension and in the initial and final $\mathrm{pH}$ values of the cultures.

The method of formation of propionate from lactate and pyruvate by propionibacteria has remained uncertain. Werkman \& Wood (1942) reviewed the various mechanisms suggested for the formation of propionic acid and made two proposals. The first was that water is removed from lactate to form acrylic acid which is then reduced to propionic acid. They regarded this as the most probable mechanism, though the reduction of acrylic acid by propionibacteria has not been demonstrated. The second possibility suggested was that the formation of propionic acid is by the decarboxylation of a symmetrical dicarboxylic acid. This was based on their experiments with isotopes and on unpublished evidence that the decarboxylation of succinate can occur by a reaction with a $\mathrm{pH}$ optimum of $5 \cdot 2$. Wood \& Werkman (1942) conclude by saying: 'Frankly, sufficient data is not available with which to formulate a defensible scheme.'

In the present paper evidence is presented that the formation of propionic acid by the decarboxylation of succinate does occur in Propionibacterium as has been demonstrated with Veillonella gazogenes (Johns, 1951). Similar evidence, based on work with Propionibacterium pentosaceum, has been published by Delwiche (1948) since the completion of this work (Johns, 1948).

\section{EXPERIMENTAL}

\section{Methods}

Succinic acid was estimated by the procedure of Umbreit, Burris \& Stauffer (1945); glucose by the method of Hassid (1937); volatile acids by the chromatographic method of Elsden (1946). The accuracy of the latter method for mixtures of acetic and propionic acids was found to be $\pm 3 \%$ with a satisfactory preparation of the silica gel. Lactic acid was estimated by the method of Friedemann \& Graeser (1933). The general purposes salt mixture of Stephenson (1948) with $0.4 \%$ Difco yeast extract was used as the basal medium for growing bacteria.

Organisms used. The strains of propionic acid bacteria used were $\boldsymbol{P}$. shermanii E11.1 and P. zeae E8.1 kindly supplied by Prof. C. B. van Niel. A dried preparation of $\boldsymbol{P}$. shermanii was made according to the method of Barker \& Lipmann (1944). 


\section{RESULTS}

$P$. zeae was grown at $30^{\circ}$ for $40 \mathrm{hr}$. in the basal medium with $1 \%(\mathrm{v} / \mathrm{v}) \mathrm{Na}$ lactate solution (c.50\%) added. The cells were spun down, washed twice with distilled water and taken up in phosphate buffer of $\mathrm{pH} \mathrm{5.3.} \mathrm{The} \mathrm{results} \mathrm{of} \mathrm{the}$ action of this suspension are shown in Table 1, which shows that there was an evolution of $\mathrm{CO}_{2}$ (identified by using manometers with $20 \% \mathrm{NaOH}$ in the centre well) with succinate, but that the rate of evolution decreased rapidly with time.

Table 1. Decarboxylation of succinate by washed suspensions of Propionibacterium zeae grown $40 \mathrm{hr}$. at $30^{\circ}$

Bacterial suspension in buffer, $2 \mathrm{ml}$. (12 mg. dry weight $/ \mathrm{ml}$ ), $0.2 \mathrm{ml}$. $0 \cdot 1 \mathrm{~m}$ succinate; $0 \cdot 5 \mathrm{ml} .0 \cdot 1 \mathrm{M}$-phosphate buffer (pH 5.3) in side bulb with succinate.

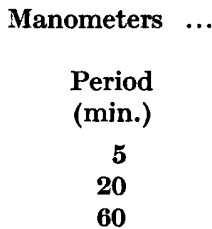

\begin{tabular}{|c|c|}
\hline \multicolumn{2}{|c|}{$\begin{array}{c}\text { Succinate } \\
\left(\mu 1 . \mathrm{CO}_{2}\right)\end{array}$} \\
\hline 15 & 16 \\
\hline 39 & 41 \\
\hline 64 & 68 \\
\hline
\end{tabular}

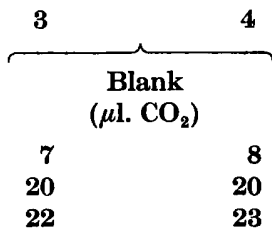

23

$Q_{\mathrm{CO}_{2}}$ for first $5 \mathrm{~min} ., 4.5$; for first $20 \mathrm{~min} ., 2.5$; for first $60 \mathrm{~min} ., 1 \cdot 75$.

Attempts were made to increase the rate of decarboxylation. It was thought that if cell permeability were a controlling factor dried cells might show an increased permeability to succinate. A dried preparation of $\boldsymbol{P}$. shermanii was made from $10 \mathrm{l}$. of bacteria grown in $1 \%(\mathrm{v} / \mathrm{v}) \mathrm{Na}$ lactate + basal medium at $30^{\circ}$ for 5 days. These cells were active with pyruvate, having a $Q_{\mathrm{Co}_{2}}$ of $2 \cdot 5$ compared with a $Q_{\mathrm{CO}_{2}}$ for fresh cells of $5 \cdot 2$, and kept well in a vacuum desiccator at $4^{\circ}$.

An experiment to determine the $\mathrm{pH}$ optimum of the decarboxylation reaction using $20 \mathrm{mg}$. dried bacteria/ml. is shown in Fig. 1. The $\mathrm{pH}$ optimum for $\mathrm{CO}_{2}$ evolution was about $\mathrm{pH} 5$ and the rate fell off sharply below this $\mathrm{pH}$ and above $\mathrm{pH}$ 6. The $\boldsymbol{Q}_{\mathrm{CO}_{2}}$ at $\mathrm{pH} 5$ was $0 \cdot 35$ as compared with a $\boldsymbol{Q}_{\mathrm{CO}_{2}}$ of $0 \cdot 48$ with fresh cells.

The effect of detergents on the rate of succinate decarboxylation was tried with fresh cells. Neither an anionic (Aerosol O.T.) nor a cationic (CTAB) detergent over a wide range of concentrations increased decarboxylation but rather inhibited it. A third possibility for increasing the $Q_{\mathrm{CO}_{2}}$ when using succinate was the provision of a source of energy for the transference of succinate more rapidly across the cell wall; but rather than an increase in the rate of succinate utilization in the presence of pyruvate or lactate, there was a significant decrease. All efforts to prepare a cell-free extract which would decarboxylate succinate, from fresh or dried cells of $\boldsymbol{P}$. shermanii, were unsuccessful.

It was difficult to carry out a balance experiment on the decarboxylation of succinate as the reaction proceeded so slowly that a long period of incubation or a large quantity of bacteria would be needed to obtain a reasonable con- 
version. It was decided that the easiest and most satisfactory method would be to carry out a growth experiment in which glucose and succinate together were fermented, with a fermentation of glucose alone as a control. In this case growth would result from the fermentation of glucose, the $\mathrm{pH}$ would fall and if the organisms were able to decarboxylate succinate they should do so at the acid $\mathrm{pH}$.

Two identical manometers were used with $100 \mathrm{ml}$. flasks. The medium in both flasks was adjusted to $\mathrm{pH} \mathrm{6.5} \mathrm{(by} \mathrm{glass} \mathrm{electrode);} \mathrm{glucose} \mathrm{was} \mathrm{sterilized}$ separately and identical amounts added to each flask. Both flasks were inoculated with $5 \mathrm{ml}$. of a 5 -day culture of $P$. shermanii grown on sodium lactate. Samples were removed with sterile precautions for the initial determinations of glucose and succinate. The whole fermentation was carried out under sterile conditions in an atmosphere of nitrogen at $\mathbf{3 7}^{\circ}$. Manometer readings were taken twice daily until gas production ceased. The two sets of manometer readings corrected to N.T.P. are plotted in Fig. 2.

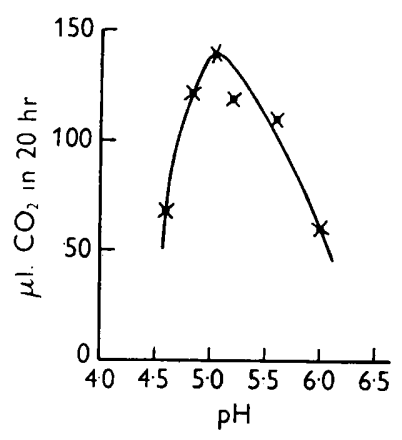

Fig. 1

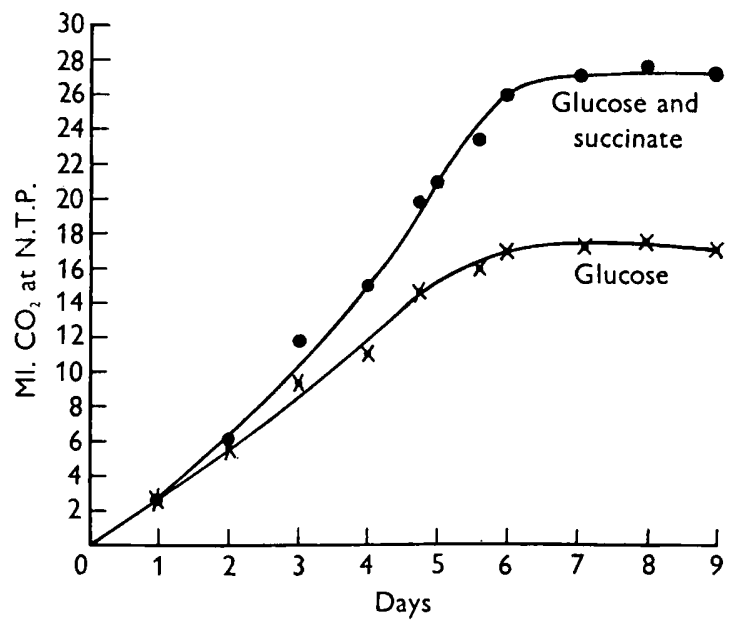

Fig. 2

Fig. 1. Rate of decarboxylation of succinic acid by dried cells of $P$. shermanii at different pH values.

Fig. 2. The effect of succinate on the production of $\mathrm{CO}_{2}$ by $P$. shermanii grown with glucose.

When the fermentation had ceased the dissolved $\mathrm{CO}_{2}$ in the fermentation liquid was determined by the method described by Peters \& van Slyke (1932) for urine. The results are given in Table 2. The final acid figures include the amounts added in the inoculum; these were the same in both flasks. The 'initial succinate' in the glucose $\operatorname{control} B$ was that added with the inoculum. Neglecting the slight difference $(0.02 \mathrm{mmol}$.) in the amount of glucose fermented and the acetic acid produced (0.01 $\mathrm{mmol}$.), $0.48 \mathrm{mmol}$. of succinate disappeared to give rise to $0.51 \mathrm{mmol}$. of propionic acid and $0.46 \mathrm{mmol}$. of $\mathrm{CO}_{2}$. The final $\mathrm{pH}$ was $4 \cdot 4$.

In spite of the large inoculum used it will be noticed from Fig. 2 that the complete fermentation of glucose took 6 days. This emphasizes the slow rate of 
Table 2. $A$ comparison of the amount of $\mathrm{CO}_{2}$ and propionic acid produced by Propionibacterium shermanii in the fermentation of: $A$, glucose + succinate; $B$, glucose alone

Manometer $A, 50 \mathrm{ml}$. basal medium (pH 6.5) and glucose $+1.5 \mathrm{ml} .0 \cdot 1 \mathrm{~m}$ sodium succinate. Manometer $B$, the same except for $1.5 \mathrm{ml}$. distilled water in place of sodium succinate. Temp. $37^{\circ}$, gas phase $\mathbf{N}_{2}$.

$\begin{array}{lcc} & \begin{array}{c}\boldsymbol{A} \\ (\mathrm{mmol})\end{array} & \begin{array}{c}\boldsymbol{B} \\ (\mathrm{mmol})\end{array} \\ \text { Glucose fermented } & \mathbf{1 \cdot 3 2} & \mathbf{1 \cdot 3 0} \\ \text { Succinate fermented } & \mathbf{0 \cdot 4 9} & \mathbf{0 \cdot 0 1} \\ \text { Final propionate } & \mathbf{2 \cdot 7 6} & \mathbf{2 \cdot 2 5} \\ \text { Final acetate } & \mathbf{0 \cdot 7 6} & \mathbf{0 \cdot 7 5} \\ \text { Total CO } & \mathbf{1 \cdot 4 0} & \mathbf{0 \cdot 9 4} \\ \text { Excess propionate } & 0 \cdot 51 & - \\ \text { Excess acetate } & 0 \cdot 01 & - \\ \text { Excess } \mathrm{CO}_{2} & 0 \cdot 46 & -\end{array}$

growth of the propionibacteria, and emphasizes the fact that it would not require a high rate of succinate decarboxylation to account for all the propionic acid produced. This experiment confirms the indications given by the washed suspension experiments that propionibacteria can decarboxylate succinate to propionic acid and carbon dioxide at pH values below 6 .

The theoretical equation for the fermentation of glucose by propionibacteria is

$$
3 \mathrm{C}_{6} \mathrm{H}_{12} \mathrm{O}_{6}=4 \mathrm{C}_{2} \mathrm{H}_{5} \mathrm{COOH}+2 \mathrm{CH}_{3} \cdot \mathrm{COOH}+2 \mathrm{CO}_{2}+2 \mathrm{H}_{2} \mathrm{O}
$$

giving a propionic acid:acetic acid ratio of $2: 1$. This ratio has rarely been observed. In a previous paper (Johns, 1950) it was demonstrated that the $\mathrm{CO}_{2}$ concentration in the medium influenced the acetic to propionic acid ratio during the fermentation of lactate by Veillonella gazogenes. These experiments were repeated with Propionibacterium shermanii using three different concentrations of $\mathrm{CO}_{2}: A$ was carried out in a sealed tube with added sodium carbonate so that the fermentation finished up with $\mathrm{CO}_{2}$ under pressure; $\boldsymbol{B}$ was similar to $A$ but without sodium carbonate, not sealed, and incubated

Table 3. Effect of $\mathrm{CO}_{2}$ concentration on the fermentation of lactate by Propionibacterium shermanii

Incubation time 14 days at $30^{\circ} ; \mathrm{pH} \mathrm{7.2.} \mathrm{Lactate} 6$ mmol. in each tube; $20 \mathrm{ml}$. basal medium. Acid production in mmol.

Tube

Propionic acid (P)

Acetic acid (A)

Ratio P/A

$\begin{array}{cc}A, & B, \\ 2 \text { mmol. } \mathrm{Na}_{2} \mathrm{CO}_{3} & \begin{array}{c}B \text { unsealed } \\ \text { tube }\end{array} \\ \text { tube sealed } & 3 \cdot 38 \\ 3 \cdot 45 & 1 \cdot 72 \\ 1 \cdot 61 & 1 \cdot 96 \\ 2 \cdot 14 & \end{array}$

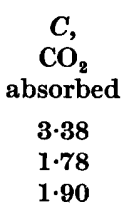

anaerobically; $C$ was carried out in a $50 \mathrm{ml}$. volumetric flask to which was connected a second flask containing $20 \mathrm{ml}$. of alkaline pyrogallol to absorb the $\mathrm{CO}_{2}$ produced during the experiment and to maintain anaerobic conditions. The results are shown in Table 3. As can be seen (from the results), there is 
a slightly higher ratio with the fermentation carried out in excess $\mathrm{CO}_{2}$ as compared with that in which the $\mathrm{CO}_{2}$ was absorbed, but the difference could hardly be considered convincing. In this experiment there was little change in acidity. Three molecules of lactic acid give rise to three molecules of volatile acid (two of propionic acid, one of acetic acid).

The above experiment was repeated with glucose as the substrate, when a considerable increase in acidity occurred. The results are presented in Table 4.

Table 4. The effect of the $\mathrm{CO}_{2}$ concentration on fermentation of glucose by Propionibacterium shermanii

6 mmol. glucose in each flask; pH 6.5 ; temperature $30^{\circ}$, acid production measured in mmol.

$\begin{array}{lccc} & \begin{array}{c}2 \text { mmol. } \mathrm{Na}_{2} \mathrm{CO}_{3} \\ \text { tube sealed }\end{array} & \text { Tube open } & \begin{array}{c}\mathrm{CO}_{2} \\ \text { absorbed }\end{array} \\ \text { Propionic acid (P) } & 1 \cdot 14 & 1 \cdot 00 & 1.04 \\ \text { Acetic acid (A) } & 0 \cdot 32 & 0 \cdot 35 & 0.59 \\ \text { Ratio P/A } & 3 \cdot 56 & 2 \cdot 80 & 1.76\end{array}$

It will be seen in Table 4 that the increase in $\mathrm{CO}_{2}$ tension led to a higher propionic:acetic ratio in the fermentation of glucose. No doubt this is in part the explanation of the widely varying ratios of propionic:acetic reported in the literature. The experiments of previous investigators have been carried out under varying conditions of $\mathrm{pH}$ and with different types of buffer.

\section{DISCUSSION}

Lactate and pyruvate are readily converted into propionate by propionibacteria, hence it was generally assumed (Kluyver, 1931) that lactate was an intermediate in the reduction of pyruvate, i.e. pyruvate $\rightarrow$ lactate $\underset{\mathbf{2 H}}{\rightarrow}$ propionate. Wood \& Werkman (1936) introduced the concept of heterotrophic utilization of $\mathrm{CO}_{2}$ in connexion with their studies on the fermentation of glycerol by propionibacteria. Wood \& Werkman (1938) proposed that succinic acid was formed in the fermentation by the combination of a $\mathbf{C}_{\mathbf{1}}$ and a $\mathrm{C}_{\mathbf{3}}$ compound. Krebs \& Eggleston (1941) showed that the set of reactions from oxaloacetate to succinate occurred in the propionibacteria (oxalacetate $\rightleftharpoons$ malate $\rightleftharpoons$ fumarate $\rightarrow$ succinate). Carson \& Ruben (1940) using $\mathrm{C}^{11}$ and Wood, Werkman, Hemingway \& Nier (1940, 1941) using $\mathrm{C}^{13}$, confirmed that fixation occurred and that the labelled $\mathrm{CO}_{2}$ appeared in the carboxyl group of succinic acid. However, quite unexpectedly, labelled carbon was also found in the carboxyl group of propionic acid. Both Carson, Foster, Ruben \& Barker (1941), and Krebs \& Eggleston (1941) explained the presence of isotopic carbon in propionic acid by postulating that the fixation process proceeded by the same pathway as for the formation of succinic acid but only as far as fumaric acid, and that by a reversal of these steps propionic acid was formed by reduction of the pyruvic acid which then contained the labelled carbon in its carboxyl group. Neither groups of workers demonstrated any decarboxylation of succinate. Barker \& Lipmann (1944), working with dry preparations of $\boldsymbol{P}$. pentosaceum, found, on the basis of fluoride 
inhibition studies, that lactate was not on the normal pathway from pyruvate to propionate.

The quantitative studies of Werkman \& Wood (1942), in which they found equal concentrations of $\mathrm{C}^{13}$ in the carboxyl groups of the succinic and propionic acids, find their simplest interpretation in the presence of a succinic decarboxylase in the bacteria. The results presented above, and those of Delwiche (1948), demonstrate that propionibacteria are able to decarboxylate succinic acid below a $\mathrm{pH}$ of $6 \cdot 0$ at a rate sufficient to justify the assumption that this reaction is concerned in the production of propionic acid. Shaw \& Sherman (1923) and Hitchner (1934) claimed to have demonstrated the fermentation of succinate with propionibacteria, but in both cases the utilization of succinate was only achieved under aerobic conditions. The experiments of Fromageot \& Bost (1938) with washed suspensions of $\boldsymbol{P}$. pentosaceum indicated that succinate was attacked only in the presence of glucose, but Krebs \& Eggleston (1941) could not confirm this. The results of Fromageot \& Bost (1938) are readily explained by the fact that the fermentation of glucose lowered the $\mathrm{pH}$ sufficiently to permit succinic decarboxylase activity. Krebs \& Eggleston (1941) used bicarbonate buffer where a marked drop in $\mathrm{pH}$ does not take place. In the present work lactate or pyruvate in addition to succinate gave no increase in the rate of $\mathrm{CO}_{2}$ evolution from succinate.

Although the equations for the fermentation of lactate (Fitz, 1878, 1879, 1880), and glucose by propionibacteria, have been established for a long time the ratio of $2: 1$ for propionic:acetic acid has rarely been obtained. The explanations for this variability in volatile acid ratio have previously centred round hypothetical pathways for anaerobic utilization of acetate (Wood \& Werkman, 1938). Krebs \& Eggleston (1941) rejected Wood \& Werkman's hypothesis and suggested that acetate was oxidized to $\mathrm{CO}_{2}$, but produced no convincing evidence to support this. Carson (1948) obtained indications in isotope experiments with propionibacteria that acetate was metabolized through a condensation reaction which subsequently yielded $\mathrm{CO}_{2}$. The degree of importance of this reaction depended on the state of oxidation of the substrate. The amount of initial $\mathrm{C}^{14}$ acetate which was converted to $\mathrm{C}^{14} \mathrm{O}_{2}$ was $2 \%$ with glycerol as substrate and $\mathbf{3 3} \%$ with pyruvate.

If the main method of propionic acid formation is by succinate decarboxylation, it would be expected that the amount of propionic acid present would be dependent on the concentration of $\mathrm{CO}_{2}$ in the medium. Elsden (1938) showed with Escherichia coli that the amount of succinic acid formed in the fermentation of pyruvate, glucose and galactose was influenced by the $\mathrm{CO}_{2}$ concentration in the medium.

With propionibacteria a large effect of $\mathrm{CO}_{2}$ concentration on the propionic: acetic ratio was only found with a substrate whose dissimilation caused an increase in acidity and so allowed the extra succinic acid formed in the presence of $\mathrm{CO}_{2}$ to be decarboxylated.

There is always a tendency to obtain a higher propionic:acetic ratio with glucose than with lactate, e.g. in the present work the highest ratio with lactate was $2 \cdot 14$, while with glucose it was $3 \cdot 56$. As glucose and lactate are at 


\section{Propionic acid formation by propionibacteria}

the same redox level this difference in propionic: acetic ratio cannot be explained by the difference in the amounts of acetate converted to $\mathrm{CO}_{2}$ due to their different levels of oxidation as indicated by the experiments of Carson (1948).

It appears that the large variations reported in the literature for the ratio of propionic acid:acetic acid in fermentations of glucose and lactate by propionibacteria can be explained on differences in $\mathrm{CO}_{2}$ concentration in the medium. Evidently succinic acid can pass out of the bacterial cell at $\mathrm{pH}$ values above c. 6.5 but cannot re-enter until the $\mathrm{pH}$ drops below that level. When the $\mathrm{CO}_{2}$ concentration in the medium is increased, more succinic acid is formed, the excess passes out into the medium and can only be decarboxylated when the pH falls giving a high propionic: acetic ratio.

Van Niel (1928) found that the propionic:acetic ratio was always less than 2 in lactate fermentations with propionibacteria, and always greater than 2 with glucose as substrate. The explanation seems to be that he absorbed the $\mathrm{CO}_{2}$ produced in his lactate fermentations, and added $\mathrm{CaCO}_{3}$ to neutralize the acid produced during the glucose dissimilation.

Foote, Fred \& Peterson (1930), in glucose fermentation experiments with propionibacteria, did not allow the $\mathrm{pH}$ to fall, but neutralized the acidity with $\mathrm{NaOH}$ daily. The highest propionic: acetic ratio was $2 \cdot 16$ and large amounts of succinic acid accumulated. In one case $\mathrm{CaCO}_{3}$ was used in the medium instead of the daily neutralization and this gave a propionic: acetic ratio of $\mathbf{2 \cdot 8 5}$. Wood \& Werkman (1934), in an experiment on glucose fermentation with $\mathrm{NaHCO}_{3}$ as buffer, analysed the fermentation liquid at intervals. The $\mathrm{pH}$ remained constant at $\mathbf{7 \cdot 2}$ until just before the end of the experimental period of 14 days. The ratio of propionic to acetic acid remained constant at about $\mathbf{2} \cdot 4$ during this time, while the amount of succinic acid steadily increased. Wood \& Werkman (1936) used $\mathrm{CaCO}_{3}$ as the buffer and found that the $\mathrm{pH}$ dropped from 7.0 to $\mathbf{5 . 5}$ during the fermentation of glucose, the amount of succinic acid formed decreased and the propionic:acetic ratio steadily increased.

Delwiche (1948) made an analysis of a fermentation broth for volatile acids at varying times and $\mathrm{pH}$ intervals throughout the fermentation. Significant amounts of propionic acid did not appear until the $\mathrm{pH}$ was below 6.5 and the peak of production was at a $\mathrm{pH}$ below 6 . The ratio of propionic to acetic acid rose steadily from $0 \cdot 7: 1$ at $23 \mathrm{hr}$. to $2 \cdot 35: 1$ at $41 \mathrm{hr}$. and there was no indication of a utilization of acetate of any period.

There were indications in the present work that there may be strain differences in the propionic:acetic acid ratio produced under the same conditions; this was indicated by the work of van Niel (1928).

The factors which appear to influence the propionic:acetic acid ratio in fermentation of glucose by propionibacteria may be summarized as follows: (a) the $\mathrm{CO}_{2}$ tension in the medium; (b) the initial and final $\mathrm{pH}$ of the medium, the initial $\mathrm{pH}$ influencing the amount of succinic acid formed and the final pH determining how much will be decarboxylated; (c) the strain of Propionibacterium; $(d)$ with the more oxidized substrates such as pyruvate the conversion of acetate to $\mathrm{CO}_{2}$ evidently becomes important (Carson, 1948).

It seems quite clear therefore that in at least two bacterial species, Propioni- 
bacterium and Veillonella gazogenes, the main mechanism of propionic acid production is by the decarboxylation of succinic acid. Whether there is a second mechanism for propionic acid formation in bacterial fermentations is not yet clear. Cardon \& Barker (1947) studied an anerobic alanine-fermenting bacterium, Clostridium propionicum, which produces acetic acid, propionic acid and $\mathrm{CO}_{2}$ from alanine and lactate. It rapidly converts acrylate to propionate (which Propionibacterium does not), and is inactive against malate and fumarate. It would be of interest to determine whether this organism fixes $\mathrm{CO}_{2}$ in propionic acid.

My thanks are due to Dr S. R. Elsden for his help and advice in the carrying out of this work and for reading the proofs.

\section{REFERENCES}

Barker, H. A. \& Lipmann, F. (1944). On lactic acid metabolism in propionic acid bacteria and the problem of oxido-reduction in the system fatty-hydroxy-keto acid. Arch. Biochem. 4, 361.

Cardon, B. P. \& Barker, H. A. (1947). Amino acid fermentations by Clostridium propionicum and Diplococcus glycinophilus. Arch. Biochem. 12, 165.

Carson, S. F. (1948). Design and interpretation of carbon isotope experiments in bacterial metabolism. Cold. Spr. Harb. Sym. quant. Biol. 13, 75.

Carson, S. F., Foster, J. W., Ruben, S. \& Barker, H. A. (1941). Radioactive carbon as an indicator of carbon dioxide utilization. V. Studies on the propionic acid bacteria. Proc. nat. Acad. Sci., Wash., 27, 229.

Carson, S. F. \& Ruben, S. (1940). $\mathrm{CO}_{2}$ assimilation by propionic acid bacteria studied by the use of radioactive carbon. Proc. nat. Acad. Sci., Wash., 26, 418.

Delwiche, E. A. (1948). The mechanism of propionic acid formation by Propionibacterium pentosaceum. J. Bact. 56, 811.

ElsDen, S. R. (1938). The effect of $\mathrm{CO}_{2}$ on the production of succinic acid by Bact. coli commune. Biochem. J. 32, 187.

ElsDen, S. R. (1946). The application of the silica gel partition chromatogram to the estimation of volatile fatty acids. Biochem. J. 40, 252.

Fitz, F. (1878, 1879, 1880). Quoted by Niel, C. B. van, 1928. The propionic acid bacteria. Thesis: Delft.

Foote, M., Fred, E. B. \& Peterson, W. H. (1930). The fermentation of pentoses by propionic acid bacteria. Zbl. Bakt. (2. Abt.) 82, 379.

Friedemann, T. E. \& Graeser, J. B. (1933). Determination of lactic acid. J. biol. Chem. 100, 291.

Fromageot, C. \& Bost, G. (1938). La fermentation du glucose par quelques bactéries propioniques croissant en 'milieux definés'. Enzymologia, 4, 225.

HASSID, W. Z. (1937). Determination of sugars in plants. Industr. Engng Chem. (Anal. ed.), 9, 228.

Hitchner, E. R. (1934). Characteristics of propionic acid bacteria. J. Bact. 28, 473.

Johns, A. T. (1948). The mechanism of propionic acid formation in bacterial fermentation. Thesis: Cambridge.

Johns, A. T. (1951). The mechanism of propionic acid formation by Veillonella gazogenes. J. gen. Microbiol. 5, 326.

Kluyver, A. J. (1931). The Chemical Activities of Micro-organisms. London: University of London Press.

Krebs, H. A. \& Eggleston, L. V. (1941). Biological synthesis of oxalacetic acid from pyruvic acid and $\mathrm{CO}_{2}$, the mechanism of carbon dioxide fixation in propionic acid bacteria. Biochem. J. 35, 676 .

Niel, C. B. van (1928). The propionic acid bacteria. Thesis: Delft. 
Peters, J. B. \& van Slyke, D. D. (1932). Quantitative Clinical Chemistry, 2nd vol. Baltimore: Williams \& Wilkins Co.

Shaw, R. H. \& Sherman, J. M. (1923). 'The production of volatile fatty acids and carbon dioxide with special reference to their action in cheese. J. Dairy Sci. 6, 303.

Stephenson, M. (1949). Bacterial Metabolism. 3rd ed. London: Longmans, Green $\&$ Co.

Umbreit, W. W., Burris, R. H. \& Stauffer, J. F. (1945). Manometric Techniques and Related Methods for the Study of Tissue Metabolism. Minneapolis: Burgess Publishing Co.

Werkman, C. H. \& Wood, H. G. (1942). Heterotrophic assimilation of carbon dioxide. Advances in Enzymology, 2, 135.

Wood, H. G. \& Werkman, C. H. (1934). Pyruvic acid in the dissimilation of glucose by the propionic acid bacteria. Biochem. $J .28,745$.

Wood, H. G. \& Werkman, C. H. (1936). Mechanism of glucose dissimilation by the propionic acid bacteria. Biochem. J. 30, 618.

Wood, H. G. \& Werkman, C. H. (1938). The ultilization of $\mathrm{CO}_{2}$ by the propionic acid bacteria. Biochem. J. 32, 1262.

Wood, H. G., Werkman, C. H., Hemingway, A. \& Nier, A. O. (1940). Heavy carbon as a tracer in bacterial fixation of carbon dioxide. J. biol. Chem. 135, 789.

Wood, H. G., Werkman, C. H., Hemingway, A. \& Nier, A. O. (1941). Heavy carbon as a tracer in heterotrophic carbon dioxide assimilation. J. biol. Chem. 139, 365.

(Received 1 February 1950) 